\title{
Kamu Yönetiminde Yenilikçi Bir Yönetişim Hedefi Olarak Kaynak Optimizasyonu: Kalkınma Ajanslarında COBIT-5 Çerçevesinde Bir Analiz
}

\begin{abstract}
Ahmet EFE ${ }^{1}$
ÖZ: Kurumsal kaynak planlamasl (ERP) ve insan kaynaklarl yönetimi (HRM) sistemleri sayesinde fiziki, beşeri, fikri ve mali kaynakların yönetimi gibi kavramlar, standartlar ile gerektirdikleri kurumsal uygulamalar işletmecilik ve kamu yönetimi alanına girmiştir. Ancak kaynak optimizasyonu yaklaşımı ise ilk defa bir yönetişim hedefi ve süreci olarak COBIT-5 ile ortaya atılmıştır. Bu çalışmada kaynak optimizasyonu ile ilgili olarak Türkiye'de kalkınma ajansları (KA) ve bölgesel gelişme dinamiklerinde yapılandırılmış bir yaklaşımın mevcut olmadı̆̆ sorunundan dolayı Devlet Denetleme Kurulu (DDK) tarafindan belirlenmiş olan kurumsal sorunların çekirdek nedenleri araştırma problemi olarak ele alınmaktadır. Araştırmamızda COBIT-5 kaynak optimizasyonu ile ilgili yönetişim süreci modelinin KA dinamiklerine uyarlanabilecek ve ilişkili kurumsal sorunlart çözebilecek şekilde modellemesinin olanakl olduğu iddia edilmektedir. COBIT-5 kaynak optimizasyonu üzerine literatürde henüz çalışma mevcut olmadiğından araştırmamızın hem literatüre katkısı ve hem de KA sorunlarına çözüm üretme yeteneği açısından önemi büyüktür. Bu çerçevede yapılan analizler sonucunda kaynak optimizasyonu sürecinin KA dinamiklerinde nasıl işletilebileceği, kilit performans göstergeleri, kriter faaliyetler ile süreçlerde sorumlu, mesul, danışılan ve bilgilendirilen rollerin neler olduğu tespit edilmeye çalışılmaktadır.
\end{abstract}

Anahtar Kelimeler: Kalkınma ajansları, bölgesel gelişme, kaynak optimizasyonu, COBIT-5 JEL Sınıflandırması: M11, O20, O24, 032, 038

\section{Resource Optimization as an Innovative Governance Goal in the Public Administration: An Analysis with COBIT-5 Framework over Regional Development Agencies in Turkey}

\begin{abstract}
Through benefits of enterprise resource planning (ERP) and human resource management (HRM) systems, implementations and requirements of concepts and standards such as physical, human, intellectual and financial resource management have been infiltrated into domain of public management discipline. However, it is interesting that the approach of resource optimization is put forward for the first time in the literature as a governance goal by COBIT-5 framework. In this study, due to lack of a systematic and professional background of resource management at the regional development agencies (KA) and insufficient ecosystem and dynamics of regional development, root-causes of the problems defined by State Auditing Board (DDK) for $K A$ are being defined and assessed as part of a solution finding research methodology. It is argued that an applicable and remedial solution could be found by resource optimization goal and its related governance processes if customized for KA dynamics and regional development ecosystem. Since there is not yet any research on applicability of COBIT-5 resource optimization in the literature, our study as a pioneering one assumes significant contribution to the area. Therefore, after the analysis and assessments it is shown that how resource optimization process can be implemented with practices and activities, KPI by required roles and responsibilities such as responsible, accountable, consulted and informed (RACI) depicted and modelled in tables for KA.
\end{abstract}

Keywords: Development agencies, regional development, resource optimization. COBIT-5 JEL Classification: M11, O20, O24, 032, 038

\footnotetext{
${ }^{1}$ Dr., CISA, İç Denetçi, Ankara Kalkınma Ajansı, aefe@ankaraka.org.tr
} 


\section{Giriş}

Küresel eğilimler ve $\mathrm{AB}$ müktesebatının gerekleri 1şı̆̆ında, Türkiye açısından geleneksel plancılıktan vazgeçilerek yerel sivil, özel, akademi ve kamu sektörünün ortak yönetişimine dayanan bölgesel kaynakların potansiyel ve dinamiklere göre belirlenecek önceliklere tahsisini esas alan yeni plancilık kültürü, kalkınma ajansları (KA) ile bölgesel kalkınmacılığa yansıtılmıştır. Türkiye'de 2006 yılında "yönetişim" paradigması üzerine kurgulanan KA, AB ilerleme raporlarındaki tespit ve önerilere uygun bir şekilde 5449 sayılı Kuruluş Kanunu ile ortaya çıkmış olmakla birlikte pek çok gelişmiş ülkede yaygın olarak kullanılan bölgesel gelişme ve sosyo-ekonomik dinamiklerin verimli bir şekilde harekete geçirilmesine olanak tanımayı amaç edinen küçük ölçekli kamu kurumları olup, yönetișim mekanizması üzerinde kurgulanmıș olmaları ve çoğu noktada özel hukuka tabi olmalarından dolayı klasik Türk amme idaresi geleneğinden ayrışmaktadırlar.

Kuruluşlarından sonraki yıllarda KA' nın varlık nedeninin sorgulanması ve KA ile ilgili zayıflıkların ve problemlerin varlığı ile ilgili olarak siyasi, bürokratik, akademik ve iş dünyasından olumsuz söylem ve değerlendirmelerin artması üzerine Cumhurbaşkanlığı Makamınca 2012 yılı sonunda görevlendirilmiş olan Devlet Denetleme Kurulu (DDK) bir yılı aşkın sürede üç vergi müfettişi ve bir Kalkınma Bankası uzmanından oluşturduğu araştırma ve inceleme ihtisas heyeti marifetiyle yaptırdığı kapsamlı çalışmalar, araştırmalar, analizler ve değerlendirmeler sonucunda 2014 yılında çıkarılan ve 830 sayfa olan devasa boyuttaki Araştırma ve İnceleme Raporunda, 43 maddede tespit edilen temel sorunlara parmak basılarak bunların giderilmesi için bazı önerilerde bulunulmuştur. $\mathrm{Bu}$ öneriler doğrultusunda Kalkınma Bakanlığı (KB) tarafından eylem planı hazırlanmış olmakla birlikte bu çalışmada öncelikle 43 adet sorunu bulunan KA kaynaklarının optimumum bir şekilde kullanılması noktasında analiz eksikliği olduğu tespit edilmiştir. Efe tarafından 2015 yılında tamamlanan doktora çalışmasında, anılan 43 sorunun kökünde yönetişim kurgusunun yanlış yapıldığ varsayımıyla COBIT-5 yönetişim çerçevesinin KA için yeniden kurgulanmayı sağlayacak şekilde uygulanabileceği ve temel sorunlarına çözüm olabileceği savunulmuştur (Efe, 2015).

KA dinamiklerinde bölgesel kaynakların optimize edilebilmesi bölgesel kalkınma amaç ve hedeflerinin gerçekleștirilebilmesi ve kaynak etkinliği açısından hayati öneme sahiptir. Çünkü özellikle merkezi plancılıkta ihtiyaçlar ve sorunlar merkezden doğru olarak tespit edilemediğinden ve mevcut beşeri ve mali sermaye ile maddi ve manevi olanaklar doğru bir şekilde tahsis edilmediğinden kaynakların yanlış kullanımı söz konusu olmasından dolayı yerel, bölgesel ve ulusal kaynaklar israf edilebilmekteydi. Bu nedenle yereldeki şartlara uygun bir şekilde gerekli planlamaların yapılarak paydaşlarla birlikte ortaya konulacak kaynakların bölgesel kalkınma hedefleri doğrultusunda seferber edilebilmesi amacıyla KA kuruluşları yapılmıştı. KA bütçeleri de sadece merkezi hükümet 
tahsisatıyla değil aynı zamanda yerel birlikler, kamu kurum ve kuruluşları ile belediyelerden de kaynak konulması prensip olarak Kanun tarafindan gerekli kılınmıştı. Ancak zamanla tahsis edilen kaynakların doğru kullanılmadığı, yandaş veya nüfuzlu kimselere proje adı altında haksız kazanç kapısı oldukları, uygulanan projelerin etkilerinin bölgesel kalkınma açısından olabildiğince önemsiz olduğu gibi değerlendirmeler yapılabilmesi bölgesel kalkınma için ayrılan kaynakların doğru kullanılmadığını ortaya koymaktadır. Dolayısıyla kaynakların optimize edilebilmesi aslında KA açısından varlık nedeninin yerine getirilip getirilmediği anlamında fikir verebilir. Uluslararası ölçekte genel kabul görmüş olan COBIT-5 yaklaşımıyla kaynak optimizasyonunun yapılabilirliğinin ortaya konulması KA açısından bazı kurumsal sorunları giderebileceği ve bölgesel gelişme hedeflerine ulaşmada yardımcı olabileceğinin ortaya konulabilmesi bu anlamda büyük öneme sahiptir. Bu çalışmadaki temel amaç da budur. Kullanılan COBIT-5 modeli de henüz 2012 yılında meydana geldiğinden dolayı kısaca temel ilke ve gerçekleştiricileri hakkında bilgi verilmesi uygun görülmüştür.

Bir paradigma olarak dikkate alınabilecek olan COBIT, önceleri denetim, kontrol ve daha sonra yönetim çerçevesi iken daha sonraları risk ve katma değer ile ilgili standartları da bünyesine alarak zamanla bir BT yönetişim çerçevesi haline gelmiştir. Her versiyonunda paradigmatik bir kırılımla kendisini yenileyen COBIT-5 versiyonunda, en sonunda sadece BT yönetişimi değil diğer iş süreçlerini de kapsayarak kapsamlı bir model haline gelen bütünlükçü, kapsayıcı ve uyarlayıcı bir çerçeve model olduğu iddiasındadır. COBIT-5 ile ortaya konulan ilkeler ve gerçekleştiriciler ile BT yönetişiminin iş süreçleri ile birlikte yönetilebilmesine olanak sağlayacak bir yönetişim ve yönetim modellemesi süreçleriyle birlikte ortaya konulmaktadır.

COBIT-5 çerçeve yaklaşımı 5 temel ilke "principles" getirmektedir. Bu ilkeler çerçevenin esas sütunlarını teşkil etmektedirler. Bu ilkeler üzerinde yapılacak olan yapısal kurgu ve süreç uygulamaları da gerçekleştiriciler "enablers" vasıtasıyla temellendirilebilmektedir.

Şekil 1' de görüldüğü gibi COBIT-5 beşinci versiyonunda beş temel ilke üzerinde kurulmuş olup bu ilkelerin kabullenilmesi COBIT-5 yaklaşımının temelini teşkil etmektedir. COBIT-5, sistem teorisinin temel varsayımlarını kullanarak birbiriyle etkileşim içerisindeki bileşkeleri dikkate alarak bütüncül bir yaklaşım sergilenmesi gerektiğini ortaya koymaktadır. Buna göre, gerçekleştiriciler kurumsal yönetişim ve yönetim açısından birbirini bütünleyen, diğer çerçeve ve standartların eksikliklerini tamamlayan, kurumun varlığını sürdürmesi için gerekli olan alt sistemlerden oluşan canlı bir sistemin birliğini tamamlamaktadır 
Şekil 1: COBIT-5 Temel İlkeleri

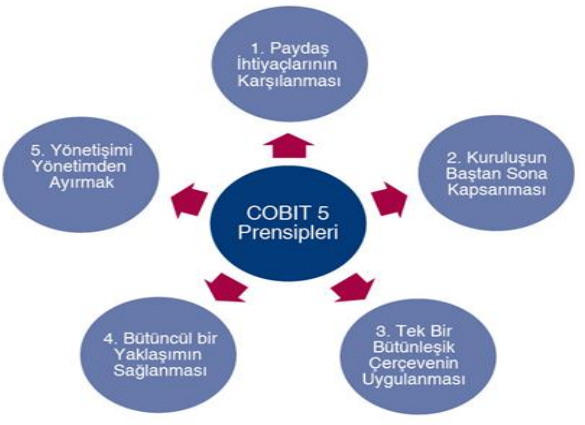

Kaynak: (ISACA, 2012: 13)' den alınmıştır.

COBIT-5 gerçekleştiricileri bütüncül yaklaşımı esas alınarak BT ve iş süreçleri ile birlikte kurumsal anlamdaki temel bileşenler gerçekleştiriciler kapsamına alınabilmektedir. COBIT-5, ABD merkezli bir sivil toplum örgütü olan ISACA tarafından geliştirilen bir BT yönetişim çerçevesidir. Şekilden de görüleceği üzere, COBIT, ilk başta finansal ve BT denetim ve kontrol alanlarında ilk önce kendisini göstermişti. İlk baştaki COBIT, "Control Objectives of IT" olarak bilinmekteydi. Daha sonra COBIT, göstergeler, süreç araçları, kritik başarı faktörleri, olgunluk modelleri ve BT yönetimi ile ilgili görev ve sorumluluklarının yerine getirilebilmesi için geliştirilen araçlarla birlikte aşamalı bir şekilde toplumsal ve ekonomik koşulların sonucu olarak yeni olarak elde edilen bilgilerle girdiği paradigma gerilimleri sonucunda bir yönetişim ve yönetim çerçevesi haline gelivermiştir.

Şekil 2: COBIT-5 Gerçekleştiricileri

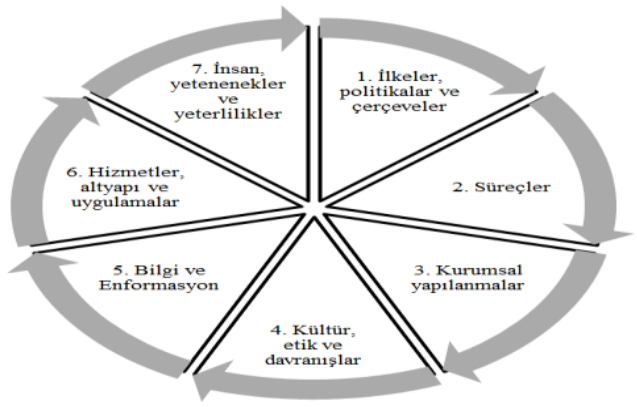

Kaynak: (ISACA, 2012: 27)' den uyarlanmıştır.

Paradigma gerilimi, diğer standart ve çerçevelerin mevcut teknik ilişkiler ağını, gereklilikleri ve sürdürülebilir stratejik yönetimi acımasız rekabet ortamında açıklayamaması ve çözüm bulamamasından dolayı ortaya çıkmıştır. Çünkü her kurumun paydaşları ve ihtiyaçları farklı olduğundan ve kaynakları ile riskleri de aynı olmadığından kendilerine has uyarlamaların yapılabilmesi aşikâr bir halde belirginleşmiştir. Kendisini çevresel koşullara ve zamanın gereklerine göre sürekli adapte edebilen COBIT bu gerilim içerisinde yeni bir paradigma olarak ortaya 
çıkarak mevut sorunlara çözüm sunma iddiasındadır. Bunun için de COBIT-5 gerçekleştiriciler yaklaşımını ortaya koyarak yedi tane bileşen ortaya koymuştur. Şekil 2'de gösterilen bu gerçekleştiricilerin her kuruma özel paydaş ihtiyaçları, kurumsal hedefler, BT ilişkili hedefleri ve gerçekleştirici hedefleri çerçevesinde yapılandırılması gerektiği savunulmaktadır.

Şekil 3: COBIT Alanında Paradigma Gerilimleriyle Yaşanan Kapsam Genişlemesi

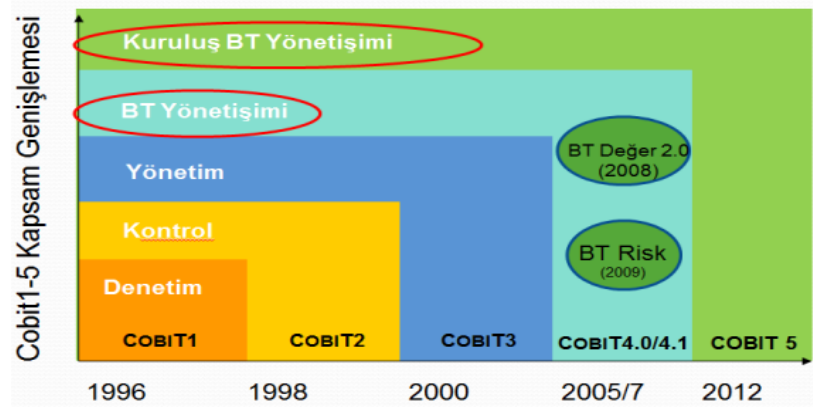

Kaynak: (ISACA, 2012: 11)’ den uyarlanmıştır.

Şekil 3' den de görüleceği üzere, COBIT-4 iş süreçlerini BT süreçleri ile hızalandırmak için bazı araçların geliştirilmesiyle ortaya çıkmış ve diğer yönetişim çerçeveleri ve BT çerçeve ve standartları ile olan ilişkileri de güçlendirmiştir. $\mathrm{Bu}$ durum elbette de $\mathrm{BT}$ ile ilişkili olan iş süreçleri ve sorumluluklarının katma değer oluşturma (Val IT) ve risklerin yönetilmesini (Risk IT) de belirlemiştir. Val IT ile Risk IT temel kavram ve süreçleri COBIT alanından alırken bunlara ilgili oldukları alanlara ait özel rehberlikler eklemişlerdir. Görüldüğü gibi COBIT-5 bir paradigma olarak yeni gelişmeler ve değerlere göre yenilikçi bir yaklaşımla sürekli değișerek gelişmeye devam etmektedir.

\section{Metodoloji}

Ebscohost veri tabanında "resource management" olarak yapılan taramada 460.865 gibi ciddi bir sayıda araştırma yapıldığı tespit edilmiştir. Bunların içerisinde Türkçe dilinde yapılmış olarak yayınların sayısı da 1.938 gibi ciddi bir rakam tespit edilmiştir. "resource optimisation" olarak yapılan araştırmada 338 adet akademik makale olduğu tespit edilmiştir. Bu araştırmalarda genel olarak kaynak optimizasyonunun hükümet, işletme ve kurum bazında ele alındığı anlaşılmaktadır. "COBIT-5" olarak yapılan taramada ise toplamda 125 ve Türkçe dilinde yazılmış sadece 1 adet yayın olduğu araştırma konumuz olan "COBIT-5 resource optimisation" olarak yapılan aramada hiç yayın olmadığı tespit edilmiştir.

Literatür içerisinde COBIT olan kaynak optimizasyonuyla ilgili her hangi bir araştırma olmadığı gibi kalkınma ajanslarında kaynak optimizasyonuyla ilgili olarak da her hangi bir çalışma olmadığı tespit edilmiştir. Ayrıca, anılan veri tabanında "kaynak optimizasyonu" olarak yapılan araştırmada ise Türkçe 
literatürde bu alanda sadece tek bir makale olduğu bunun da COBIT-5 modeline dayanmadığ 1 ancak, Bayesiyen modeli ile işletmelerde kaynak optimizasyonunun kullanılmasını konu edindiği tespit edilmiştir (Parvizi, Oghbaei ve Khayami, 2013), (Wilkin, Campbell, Moore ve Grembergen, 2013), (Bartens, Haes, Lamoen, Schulte ve Voss, 2015), (Samiotakis, 2013), (Brown, 2014). Yapılan bu çalışmalarda COBIT-5 kaynak optimizasyonu modeli kullanılmadığından bu eserlerden yararlanılmamıştır. Bu nedenle de yaptığımız araştırma yerli ve yabancı literatüre bu anlamda ciddi bir katkıda bulunmaktadır. Ancak literatür taraması kapsamında "kaynak optimizasyonu" temalı bazı çalışmaların olduğu ancak diğer bilimsel disiplinler kapsamında yapılan teknik çalışmalar olmalarından dolayı bunların çalışma konumuz olan kurumsal yönetişim sitemi veya COBIT çerçevesiyle her hangi bir ilişkisi olmadığı tespit edilmiştir.

Kaynak optimizasyonuyla ilgili diğer disiplinler kapsamında yapılan bazı çalışmalardan örnek vermekte yarar görülmüştür. Örneğin; kaynak optimizasyonunun mikro işlemcilerin performansı ve kullanılan enerji düzeyinin düşürülmesi açısından bilgisayar ve elektronik mühendisliğinde bir teknik olarak kullanılabildiği (Glenn Leary, 2007), Avusturya'da tarımda gübre kapsamında olarak kullanılan ancak ikamesi olmadığ 1 halde ciddi çevresel sorunlara yol açtığ tespit edilen fosfor maddesinin kullanımı, atık yönetimi ve tarımsal üretkenlikte yapılması gerekli olan kaynak optimizasyonunun bir yazılım aracılığıyla gerçekleştirilebildiği (L. Egle, 2004), enerji sektöründe özellikle ham petrol ile elektrik fiyatlarındaki değişimlerden ekonominin ciddi bir şekilde etkilenmemesi ve KYOTO protokolü gereğinde enerji verimliliğini sağlayacak düzenlemelere uyumun sağlanması için IPON adı altında bir entegre kaynak optimizasyonu alt yapısının kurulmuş olduğu ve bu ağ sisteminin enerji sektöründeki alıcı ve satıcılar açısından da kullanışlı olduğu (Michael Stadler, 2005), iş başvurularında başvuru esnasında sosyal güvenlik sitelerinden veri mutabakatı yapılırken güvenlik açıklarının meydana gelmesi ve yüksek miktarlı iş başvurularında vazgeçme ve fazla bekleme zamanlarının engellenmesi için yazılım mühendisliği kapsamında kaynak optimizasyonu modellerinin geliştirilebildiği (Hwang, 2004), yol ve köprü gibi büyük inşat projelerinde kaynakların sınırlı olması durumunda ciddi engellerin meydana gelmesinden dolayı kaynak planlamasının büyük önemi haiz olduğu ve dolayısıyla kaynak optimizasyonunun yapılmasıyla önemli kaynakların kritik olmayan faaliyetlere tahsis edilmesinin engellenebileceği veya projeleri iptal ettirici ya da maliyetleri arttırıcı kritik olmayan ögelerin ayıklanabileceği iddiasıyla zamanlama veya kaynak değişimlerinde esnek bir proje yönetimiyle kaynakların etkin kullanımını sağlayabilecek formül ve modellerin geliştirilebildiği (Gunnar Lucko, 2011), bir lokal internet ağında bağlantıların performansının sınırlı olmasından dolayı her hangi bir kaynağın pek çok alıcılara mesaj göndermek durumunda kalması durumunda farklı hizmet kaliteleri gerekliliklerine göre bir kaynak optimizasyonu yapılması gerektiği için ağ mimarisi ve dizaynının büyük önem arz ettiği (Moses Charikar, 2000), lineer programlamada ortanca ve varyans değerleri bilinen rastgele katsayılar elde 
edilmesinin yenilenebilir kaynak optimizasyonu modellerinde farklı yaklaşımlarla ortaya konulabildiği (John Hof, 305-323), elektrik, gaz veya su iletim haklarında her hangi bir riskli durum veya aksama meydana geldiğinde en doğru bir şekilde bunların aksamadan aktarımının sağlanabilmesi için gerekli olan kaynakların optimizasyonun formülasyon ve modellemelerle yapılabildiği (Yong Jiang, 2006) farklı araştırmalara konu edilebilmiştir. Bu çalışmalara benzer literatürde pek çok araştırma olduğu tespit edilmiştir.

Çalışmamızda ise temel olarak iki adet kitaptan (ISACA, Enabling Processes, 2012) (ISACA, 2012) yararlanılarak COBIT-5 kaynak planlaması sürecinin KA dinamikleri üzerinden analizi ve uyarlaması yapılmaktadır. Araştırmacının ayı zamanda bir uygulayıcı olmasından dolayı uygulamadaki bilgi birikimleri, karşılaşılan sorunlar ve elde edilen tecrübelere göre süreç modellemesi yapılmaya çalışılmaktadır. Bu çalışmada doğrudan tercümeye ve aktarmaya dayanan bir çalışma olmayıp, üzerinden şimdiye kadar akademik çalışma yapılmamış bir model üzerinde sorun analizi, uygunluk araştırması, uyarlama ve modelleme çalışmasıdır.

$\mathrm{Bu}$ çalışmada kalkınma ajanslarının kaynak optimizasyonu ile ilgili olabilecek sorunları analiz edilmekte ve bu amaçla da hizmete özel olduğundan dolayı yayımlanmamış olan DDK raporu incelenmiş ve süreç olgunluğu ile ilgili olarak DDK tarafından tespit edilmiş olan dört adet probleme dair çekirdek neden analizleri yapılmaktadır. Hizmete özel olan DDK raporu ve KB eylem planı üzerinde akademik araştırma yapılarak bu alandaki idari ve teknik bilgiler akademik literatüre kazandırılmaktadır.

Ayrıca COBIT-5 kaynak optimizasyonu ile ilgili betimleyici bir çalışma da yapılmaktadır. COBIT-5 kaynak optimizasyonu yönetişim süreç modeline göre KA düzleminde kaynak optimizasyonu nasıl yapılabileceği üzerinde değerlendirme yapılmaktadır. Araştırmamızın iddiası, DDK tarafından tespit edilen 2 adet sorunun KA dinamiklerinde kaynak optimizasyonu yapılmamasiyla ilişkili olduğudur. $\mathrm{Bu}$ amaçla da araştırma sorularımız; "DDK tarafindan tespit edilen sorunlardan kaynak optimizasyonu ile ilişkili olan sorun var midır? Varsa hangileridir ve nasıl ilişkilendirilebilmektedir? COBIT-5 kaynak optimizasyonu nedir ve KA dinamiklerinde nasıl uygulanabilir? " şeklinde yapılandırılmışlardır.

\section{Araştırma Problemi Analizi}

Bu çalışmada, kalkınma ajansları (KA) ile ilgili olarak 2014 yılında yayımlanan bir raporla Devlet Denetleme Kurulu (DDK) tarafindan tespit edilen bazı sorunlardan hareketle kaynak optimizasyonunun doğru bir şekilde yapılmamış olduğu araştırma problemi olarak alınmıştır. Araştırmamızın iddiası da aşağıda analiz edilen bölge kalkınma planı (BKP) ve plancıların kalite sorunu ve verilen hibelerin kuruluş amaçları doğrultusunda kullanılamadığı sorunlarının aslında yatan temel sebep, KA dinamiklerinde kaynak optimizasyonunun doğru yapılmamış olmasıdır. Bunu teyit eden DDK raporundaki anılan örnek sorunların 
COSO ve COBIT-5 modeli özelinde analizleri de yapılmaktadır. Bu da kaynakların doğru tahsis edilmemesi ve bölgesel kalkınmayı ençoklayacak program ve projelerin desteklenmemesi demektir.

\section{a. BKP ve Plancıların Kalite Sorunu}

Bölge Kalkınma Planında (BKP) söz konusu nitelik ve kalitenin sağlanması için nitelikli, yeterli ve güncel veriye sahip olunmasının yanı sıra, bölge planlaması eğitim ve becerisine sahip yeterli ve yetkin personele ihtiyaç bulunmaktadır (DDK, 2014). Ancak bunun KA uygulamalarında eksikliğinin devam ettiği görülmektedir. Kalkınma planlarının kaliteli olmaması yapılan projeksiyonların, hesaplamaların ve önceliklendirmelerin doğru olmayabileceği anlamına gelmektedir.

Tablo 1: DDK Tarafından Tespit Edilen BKP ve Plancıların Kalite Sorunu için COSO ve COBIT-5 değerlendirmesi ve Eylem Planları

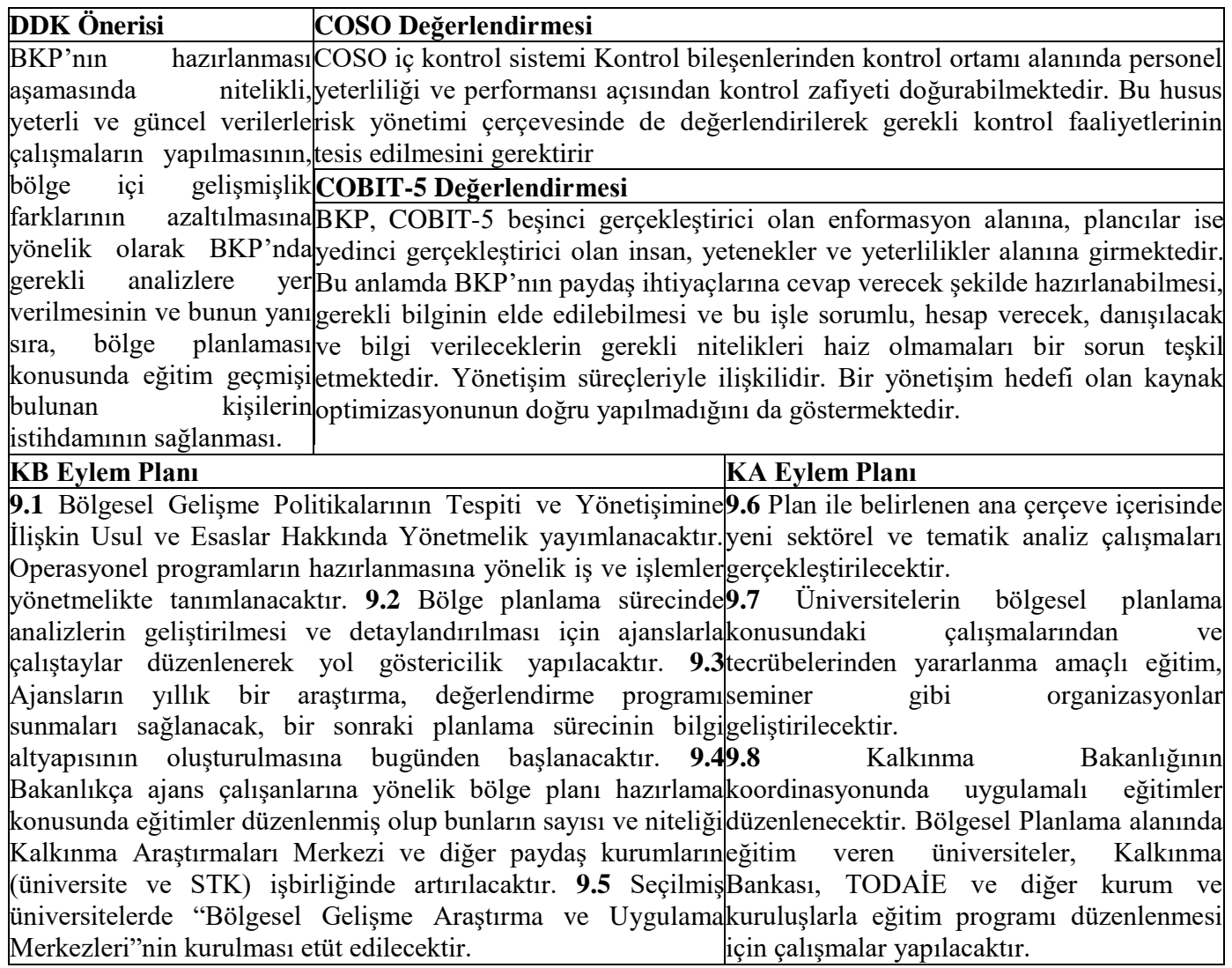

Kaynak: (DDK, 2014) ve (KB-BGYUGM, 2014)'dan yararlanarak araştırmacı tarafindan oluşturulmuştur.

Dolayısıyla kaynak optimizasyonunun yapılmamış olduğunun bir göstergesi olabilmektedir. Kaynak optimizasyonunu doğru bir şekilde yapabilmek de kalkınma planının gerekli nitelikleri haiz insan kaynağı tarafından hazırlanmasını 
gerektirir. Bu nedenle de insan kaynağının optimize edilmesiyle ilgili bir sorun olduğu söylenebilir.

\section{b. Verilen Hibelerin Kuruluş Amaçları Doğrultusunda Kullanılamadığı}

Uygulamada daha çok proje yararlanıcılarının rutin aktivitelerinin finansmanı veya söz konusu kurumların faaliyet giderlerini azaltmaya yönelik projelerin desteklenebildiği, KA'na pay veren yerel aktörlerin çoğu kez verdikleri paya yakın bir kaynağı projelere sağlanan hibeler yoluyla tekrar almalarının hakları olduğu algısına sahip oldukları, söz konusu kuruluşlarda projelere ilişkin sahiplenme düzeyinin yetersiz olduğu, proje sorumluları ve kilit personelin görev değişikliği veya görevden ayrılmaları nedeniyle projelerin sürdürülmesinde sorunlar bulunduğu, yönetim kurulu dâhil, kalkınma ajansının yönetiminde söz sahibi olan kurum ve kuruluşların projelerinin gerçekleşmelerinin etkin şekilde izlenmesi ve değerlendirilmesinde sıkıntılar yaşandığı anlaşılmıştır (DDK, 2014).

Tablo 2: DDK Tarafından Tespit Edilen Verilen Hibelerin Kuruluş Amaçları Doğrultusunda Kullanılamadığı Sorunu İçin COSO ve COBIT-5 değerlendirmesi ve Eylem Planları

\begin{tabular}{|c|c|}
\hline \multirow{4}{*}{$\begin{array}{l}\text { DDK Önerisi } \\
\text { KA sahip olduğu mali } \\
\text { destek aracının temel } \\
\text { hedefinin bölgenin içsel } \\
\text { kaynaklarını harekete } \\
\text { geçirmek ve bölgenin } \\
\text { rekabetçiliğini artırmak } \\
\text { suretiyle gelişmesine } \\
\text { katkıda bulunmak olduğu } \\
\text { hususu dikkate alınarak, } \\
\text { kamu kurum ve kuruluşlar } \\
\text { ile yerel yönetimlerin } \\
\text { projelerinin bu hedefe } \\
\text { katkısı ve sürdürülebilirliğ } \\
\text { açısından titiz bir şekilde } \\
\text { değerlendirilmesi }\end{array}$} & COSO Değerlendirmesi \\
\hline & $\begin{array}{l}\text { COSO iç kontrol sistemi Kontrol bileşenlerinden kontrol ortamı, risk yönetimi ve } \\
\text { izleme standartları alanına girmektedir. Plan ve programlar ile projelerin kaliteli } \\
\text { bir şekilde hazırlanmaması kontrol zafiyeti doğurmaktadır. Bölgenin } \\
\text { beklentilerine hitap edilmemesi ve bu alanındaki risklerin değerlendirilmemesi } \\
\text { risk standartları ile ilgilidir. Ayrıca, projelerin program ve plan çerçevesinde } \\
\text { gerekli değerlendirmesinin yapılarak süreç içerisinde faydalı sonuçlar üretecek } \\
\text { şekilde takip ve desteklenmemesi de izleme alanındaki sorunsalı teşkil etmektedir }\end{array}$ \\
\hline & COBIT-5 Değerlendirmesi \\
\hline & $\begin{array}{l}\text { Bu anlamda bir COBIT-5 paydaş analizi ve ihtiyaç tespiti yapılmalıdır. YK } \\
\text { kararıyla resen bir şekilde mali destek program mekanizması ile amaçları } \\
\text { belirlendiğinde e potansiyel başvuru sahiplerine gerekli rehberlik ve danışmanlık } \\
\text { yapılmadan projeler sunulduğunda kalkınmayla ilişkilendirilemeyecek olan ve } \\
\text { sadece yararlanıcıya menfaat sağlayan projelerin artması engellenemez. } \\
\text { Yönetişim süreçleriyle ilişkilidir. Bir yönetişim hedefi olan kaynak } \\
\text { optimizasyonunun doğru yapılmadığını da göstermektedir. }\end{array}$ \\
\hline KB Eylem Planı & KA Eylem Planı \\
\hline $\begin{array}{l}21.1 \text { Bakanlığımızca, } \\
\text { ajansların proje } \\
\text { değerlendirme sürecinde } \\
\text { proje sahipleri ve bağımsız } \\
\text { değerlendiricilere verilen } \\
\text { eğitimlerde ve mali destek } \\
\text { programlarının } \\
\text { önceliklerinde yer alması } \\
\text { konusunda düzenli } \\
\text { hatırlatmada } \\
\text { bulunulacaktır. }\end{array}$ & $\begin{array}{l}\text { 21.2 Ajanslar bölge planı öncelikleri ve geliştirdiği stratejilere katkı sağlayacak } \\
\text { proje fikirleri geliştirerek, proje havuzu oluşturacaktır. Proje fikirlerinin } \\
\text { belirlenmesinde kamu kurum ve kuruluşları, yerel yönetimler, üniversiteler ve } \\
\text { sivil toplum kuruluşları ile işbirliği yapılacaktır. Kamu kurum ve kuruluşları ile } \\
\text { yerel yönetimlerin projelerinin bölgesel kalkınma hedefine katkısı ve } \\
\text { sürdürülebilirliğinin değerlendirilmesi, rutin faaliyetlerin desteklenmemesi için } \\
\text { başvuru rehberi ile değerlendirme rehberine gerekli ifadelerin eklenmesi ve } \\
\text { değerlendirmelerde bu hususlara bağlı kalınması sağlanacaktır. 21.3 Görev devir } \\
\text { süreçleri gözden geçirilecek, personelin herhangi bir sebeple görevini devretmesi } \\
\text { durumuna ilişkin tanımlı eylemler netleştirilecektir. Personel faaliyet raporu, bilgi } \\
\text { notu ile yaptığı işlerin dökümünü ve iş süreçlerini kayda geçecektir. Faaliyet } \\
\text { raporlarının özen ve disiplinle doldurulması temin edilecek ve bunlar } \\
\text { arşivlenecektir. Projelerden sorumlu personelin görevinden ayrılması durumunda; } \\
\text { gerek ajansın diğer birimlerinden alınan gerekse de işe yeni alınan personel } \\
\text { izleme faaliyetlerine başlamadan önce sıkı şekilde oryantasyon sürecinden } \\
\text { geçirilecek ve gerekli donanıma sahip olması sağlanacaktır. }\end{array}$ \\
\hline
\end{tabular}

Kaynak: (DDK, 2014) ve (KB-BGYUGM, 2014)'dan yararlanarak araştırmacı tarafından oluşturulmuştur. 
Hibelerin kuruluş amaçları çerçevesinde kullanılmaması bölgesel kalkınma için tahsis edilen kamu kaynaklarının israf edilmesi anlamına gelmektedir. Bu bağlamında bu sorunun da kaynak optimizasyonunun yapilmamasiyla ilişsilendirilebileceği ifade edilebilir.

DDK tarafından tespit edilen ve KB tarafından uygulama önerileri çerçevesinde hazırlanan eylem planına göre gerekli önlemleri alınması gereken yukarıdaki sorunların aslında KA dinamiklerinde kaynak optimizasyonuyla ilişkilendirilebildiğini ve mali, fiziki, beşeri ve fikri kaynaklarının optimum şekilde kullanılabilmesi için gerekli süreçlerin yapılandırılmamış olmasının yukarıda bahsi geçen ve analizi yapılan sorunlara kaynak teşkil ettiğini bu çalışmada iddia ediyoruz. Bu nedenle de kaynak optimizasyonunun yapılmaması araştırma problemi olarak ele alınmakta ve bu konudaki çözümleme de COBIT-5 yaklaşımının benimsenerek uygulanmasıyla yapılabileceği savunulmaktadır. $\mathrm{Bu}$ kapsamda modelleme yapılabilmesi için öncelikle COBIT-5 süreç yaklaşımı ortaya konulmakta ve kaynak optimizasyonu süreci öncelikle betimleyici olarak verilmekte ve daha sonra KA dinamiklerine uyacak şekilde uyarlanmaya çalışılmaktadır.

\section{COBIT-5 Süreçler Yaklaşımı}

Buradaki çalışmanın amacı aşağıdaki şekilden de görüldüğü üzere COBIT-5 süreç referans modelinde öngörülen 37 ana süreçten sadece 1 yönetişim sürecindeki sorunları gidererek KA için uygulanabilecek bir model geliştirilmesi olmasından dolayı 5 yönetişim sürecinden sadece birisi olan kaynak optimizasyonu yönetişim süreci üzerinden gidilerek modelleme analiz, değerlendirme ve modelleme yapılmıștır. Ancak sistemin bütüncül olmasından ve yönetişim süreçlerinin çalışabilmesinin aynı zamanda 32 adet ana yönetim süreçlerindeki çıktılardan yararlanması gerektiğinden dolayı 32 adet ana yönetim süreçlerinin de ayrı bir çalışmaya konu edilerek modelin bütünlüğü sağlanabilir.

COBIT-5 çerçevesine göre, bir KA, temel yönetişim ve yönetim amaçları kapsandığı takdirde, süreçleri uygun gördüğü şekilde kendi kaynakları ve ihtiyaçları doğrultusunda organize edebilir. Daha küçük bir kalkınma ajansının daha az sayıda süreci olabilir; daha büyük ve daha karmaşık bir kalkınma ajansının, hepsi aynı amaçları kapsayan birden fazla süreci olabilir. KA, yapısal ve kurumsal olanaklar açısından birbirileriyle paralel olmalarından dolayı süreçlerin benzer şekilde organize edilmesi olanaklıdır. Şekil 4'teki süreçlerin her biri birbiriyle alış verişi olan bir bütünlüğü ortaya koymaktadırlar. Bu çalışmada ise yukarıda belirtildiği üzere 37 süreçten sadece kaynak optimizasyonu ile ilgili analiz, değerlendirme ve modelleme yapılabilmektedir. 
Şekil 4: Süreç Referans Modeli

Kurumsal BT Yönetișim Süreçleri

Değerlendir, Yönlendir ve lzle
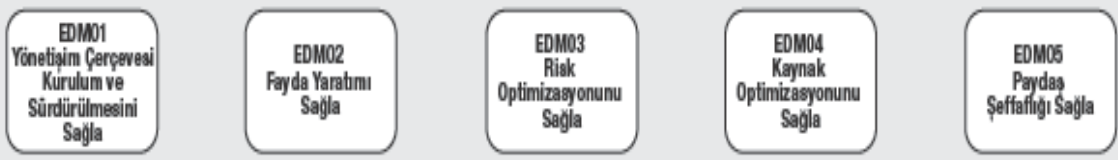

Hlzala, Planla ve Organize Et

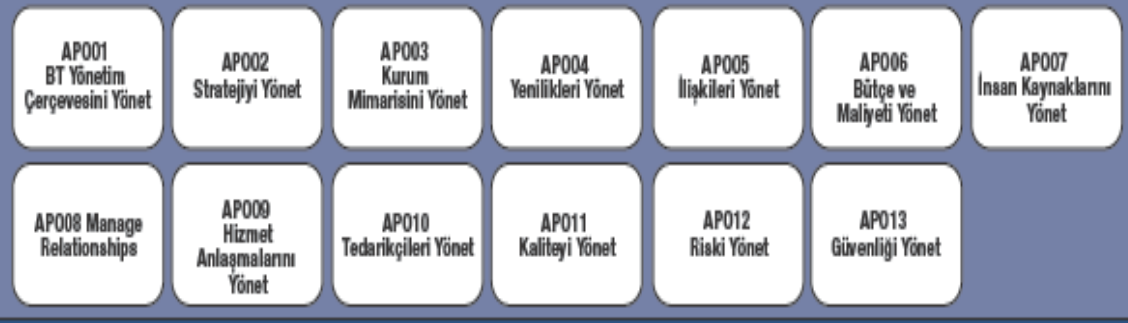

Inșa Et, Tedarik Et ve Uygula

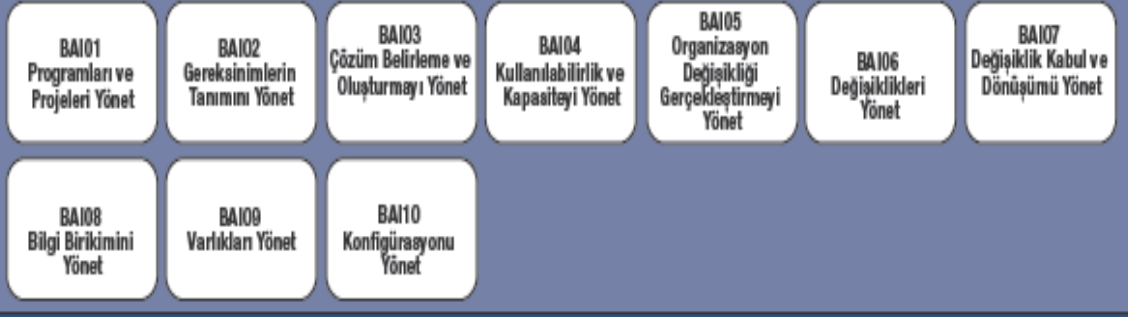

MEA01

Perfomansve

Tespitt tet ve Degentend

Tedark, Hlzmet ve Destek

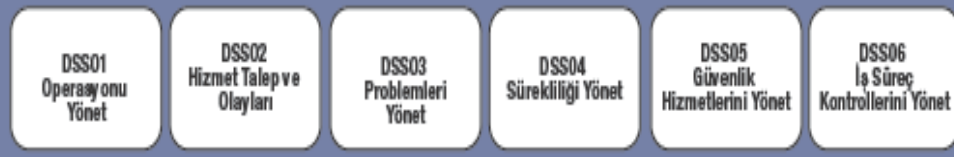

\section{Kurumsal BT Yönetim Süreçleri}

Kaynak: (ISACA, 2012: 33)' den alınmıştır.

COBIT-5 yönetişim süreçleri, 5 ana süreçten ve bu ana süreçlerin kırılımlarını oluşturan toplam 15 alt süreçlerden oluşmaktadır. COBIT-5 yönetişimin işlemesi için gerekli olan ana ve alt süreçleri tanımlarken, bu süreçlerde girdi olarak kullanılacak olan süreçlerle çıktı olan süreç ve ürünleri de tanımlamaktadır. Ayrıca her bir süreç için gerekli olan kriter faaliyetler ile kilit performans isterleri de sağlanmaktadır. 
Şekil 5: Yönetişim Ana Süreçleri ve Alt Süreç Faaliyetleri

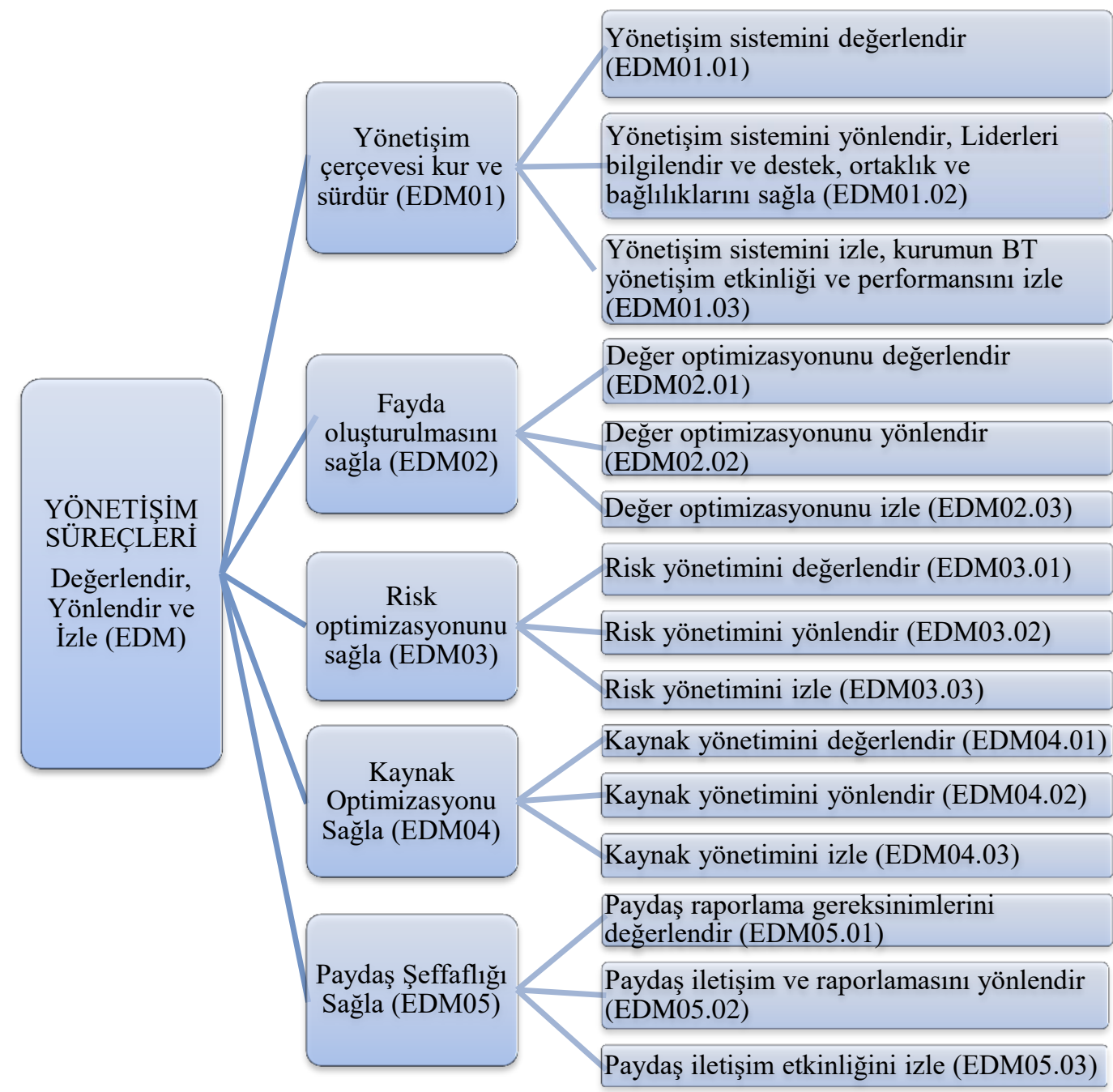

Kaynak: (ISACA, 2012: 33)' den esinlenerek araştırmacı tarafından hazırlanmıştır.

Şekil 5' de görülen yönetişim süreçlerinden sadece kaynak optimizasyonu bu araştırmaya konu edildiğinden aşağıda kaynak optimizasyonu ile ilgili analizler yapılacaktır. Aşağıdaki analizlerde öncelikle COBIT-5 kaynak optimizasyonu süreci bir yönetişim süreci olarak KA açısından yapılandırılmakta ve KA mevzuat ve sorumlulukları çerçevesi göz önünde bulundurularak bir süreç uyarlaması ve modellemesi yapılmaktadır.

\section{Kaynak Optimizasyonunu Sağlamak}

COBIT-5 ile gelinen noktada yönetişimin paydaş ihtiyaçlarının belirleme, kurumsal amaçlara dönüştürme ve bununla ilgili BT hedeflerini belirleme alanında yönlendirme, değerlendirme ve izleme olarak 3 ana süreçte belirlenmiş olup, bunların diğer yönetim süreçlerinden ayrıştırılması esası benimsenmiştir. 


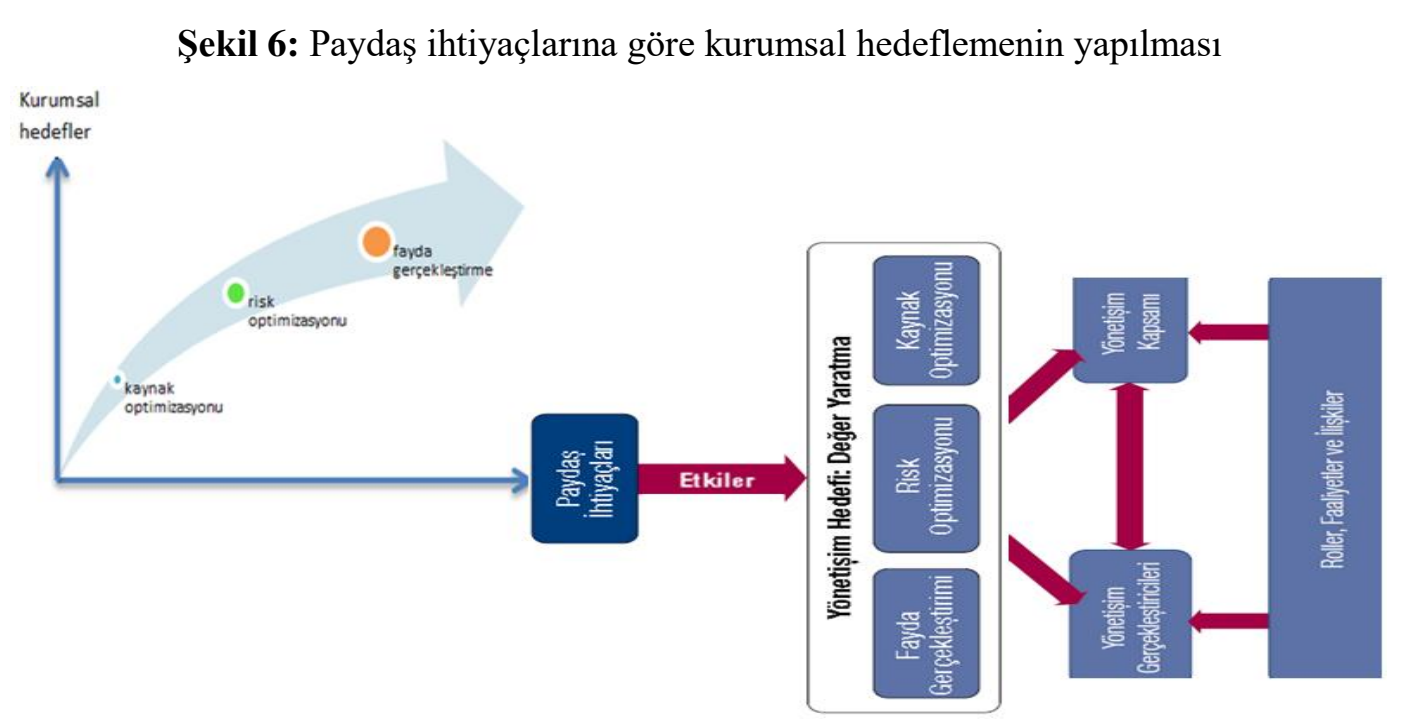

Kaynak: COBIT-5 modelinden esinlenerek araştırmacı tarafından oluşturulmuştur.

Buna göre, kurumsal yönetişim karar alma mekanizması ile kendi içerisinde bulunduğu özgün çevre ve ekosistemin içsellik ve dışşallıklarına göre değişebilen paydaş ihtiyaçlarına göre hedeflerin tekrar gözden geçirilerek mevcut kaynakların optimal kullanımı, risklerin en iyi yönetimi yoluyla katma değer oluşturacak şekilde kurumsal hedeflere ve BT ilişkili hedeflere dönüştürülerek yönetime yön verme mekanizması olarak anlaşılmaktadır. Paydaş ihtiyaçları ile kurumsal hedeflenmelerin tutarlılığı nispetinde kaynak ve risk optimizasyonu yapılarak katma değer elde edilebilir. Buradaki risk optimizasyonu,, kurumsal amaçları olumsuz etkileyen etkenleri mevcut kaynaklar ve elde edilecek faydanın dikkate alınmasıyla uygulanacak tedbir ve önlemlerin en iyileştirilmesidir. Bunun sağlanması için de roller, faaliyetler ve ilişkilerin yönetişim kapsam ve gerçekleştiricileri dikkate alınarak belirlenmesi gerekir.

Şekil 6 ve 7' den de görüleceği üzere, COBIT-5 yönetişim hedefi, katma değer oluşturmaktır. Bu katma değer de ancak paydaş ihtiyaçlarının yerine getirilmesi amaciyla kaynakların ve risklerin optimize edilmesiyle elde edilebilir.

Şekil 7: COBIT-5 Yönetişim Hedefi

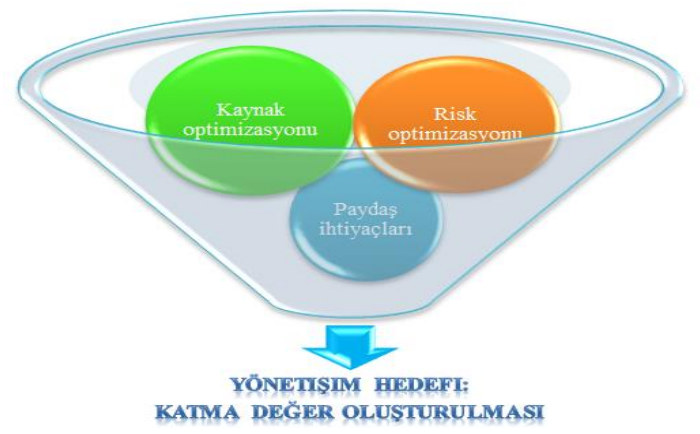

Kaynak: COBIT-5 modelinden esinlenerek araştırmacı tarafından oluşturulmuştur. 
Yeterli ve uygun BT-Bağlantılı yetkinliklerin (insan, süreç ve teknoloji) kalkınma ajansının amaçlarını optimum maliyetle etkili şekilde desteklemek amacıyla kullanılabilirliğinden emin olmak gerekmektedir (ISACA, 2012: 43). Ayrıca, kalkınma ajansının (KA) kaynak ihtiyaçlarının optimum şekilde karşılanmış olduğundan, BT maliyetlerinin optimize edildiğinden ve fayda gerçekleşme olasılığı ve gelecekteki değişikliğe hazır olmanın arttırıldığından emin olunması gerekir. $\mathrm{Bu}$ nedenle öncelikle kaynak optimizasyonunu sağlamak için her KA özelinde kurumsal hedefler belirlenmeli ve kilit performans göstergeleri belirlenebilmelidir.

Tablo 3: Kaynak Optimizasyonu Sağlamak (EDM04) İçin Hedefler ve KPI

\begin{tabular}{|c|c|}
\hline \multicolumn{2}{|l|}{ Hedefler ve Ölçütler } \\
\hline BT-Bağlantılı Hedef & Kilit Performans İsterleri \\
\hline \multirow[t]{3}{*}{ BT çevikliği } & $\begin{array}{l}\text { BT'nin yeni şartlara tepki verme yeteneğine dair iş idarecileri } \\
\text { memnuniyetinin seviyesi }\end{array}$ \\
\hline & $\begin{array}{l}\text { Güncel altyap1 ve uygulamalarla desteklenen kritik iş süreçlerinin } \\
\text { sayısı }\end{array}$ \\
\hline & $\begin{array}{l}\text { Stratejik BT amaçlarının, üzerinde anlaşılmış ve onaylanmış bir } \\
\text { girişime döndürülmesi için geçen ortalama süre }\end{array}$ \\
\hline \multirow{3}{*}{$\begin{array}{l}\text { BT varlık, kaynak ve } \\
\text { yetkinliklerinin } \\
\text { optimizasyonu }\end{array}$} & $\begin{array}{l}\text { Yetkinlik olgunluğu ve maliyet optimizasyon değerlendirmelerinin } \\
\text { sıklığı }\end{array}$ \\
\hline & Değerlendirme sonuçlarının eğilimi \\
\hline & $\begin{array}{l}\text { BT-Bağlantılı maliyetler ve yetkinlikler konusunda iş idarecileri ve } \\
\text { BT yöneticilerinin memnuniyet dereceleri }\end{array}$ \\
\hline \multirow[t]{3}{*}{$\begin{array}{l}\text { Yetkin ve istekli iş ve BT } \\
\text { personeli }\end{array}$} & $\begin{array}{l}\text { Makamı için gereken yetkinliğe ilişkin BT-Bağlantılı becerileri yeterli } \\
\text { olan kadro yüzdesi }\end{array}$ \\
\hline & BT-Bağlantılı görevlerinden memnun kadro yüzdesi \\
\hline & Her bir çalışan başına düşen sürekli öğrenme/eğitim saati sayısı \\
\hline Süreç Hedefi & Kilit Performans İsterleri \\
\hline \multirow{3}{*}{$\begin{array}{l}\text { 1. KA kaynak ihtiyaçları } \\
\text { optimum yetkinliklerle } \\
\text { karşılanır. }\end{array}$} & Kaynak optimizasyonunda paydaş geri bildirim seviyesi \\
\hline & $\begin{array}{l}\text { Kaynakların optimum kullanımıyla elde edilen fayda (ör., maliyet } \\
\text { tasarrufu) sayısı }\end{array}$ \\
\hline & $\begin{array}{l}\text { Kaynak planı ve kalkınma ajansının mimari stratejilerinden sapma } \\
\text { sayısı }\end{array}$ \\
\hline \multirow{2}{*}{$\begin{array}{l}\text { 2. Kaynaklar, KA } \\
\text { önceliklerini bütçe kısıtları } \\
\text { dahilinde en iyi şekilde } \\
\text { tahsis edilir. }\end{array}$} & Kaynak yönetim prensiplerinden ve beklentilerinden sapma sayısı \\
\hline & Uygun kaynak tahsisi olan projelerin yüzdesi \\
\hline \multirow{3}{*}{$\begin{array}{l}\text { 3. Kaynakların optimum } \\
\text { kullanımı, yaşam döngüleri } \\
\text { içinde gerçekleştirilir. }\end{array}$} & Mimari bileşenlerin tekrar kullanım yüzdesi \\
\hline & $\begin{array}{l}\text { Kaynak yönetim sorunları nedeniyle orta- veya yüksek-risk durumu } \\
\text { olan proje ve programların yüzdesi }\end{array}$ \\
\hline & Gerçekleştirilen kaynak yönetim performans hedeflerinin sayısı \\
\hline
\end{tabular}

Kaynak: (ISACA, Enabling Processes, 2012: 43)’ den uyarlanmıştır. 
Tablo 3' de, kaynak optimizasyonu sürecinin işletilmesi için kullanılması gereken süreç hedefleri ve bilişim sistemleri bağlantılı hedeflere karşılık gelen kilit performans göstergeleri geliştirilmiştir. Bu göstergeler kaynak optimizasyonu sürecinin KA dinamiklerinde kullanılması durumunda sürecin hangi aşamada olduğu hakkında bilgi verebilecektir. Aşağıdaki tabloda ise, bu süreçte KA dinamiklerinde söz sahibi olan rollerin mesul, sorumlu, danışılan ve bilgilendirilen olarak farklı kategorilerdeki işlevsellikleri tespit edilmektedir.

Tablo 4: Kaynak Optimizasyonu Sağlamak (EDM04) İçin SMDB Modeli

\begin{tabular}{|c|c|c|c|c|c|c|c|c|c|c|c|c|c|c|c|c|c|c|}
\hline 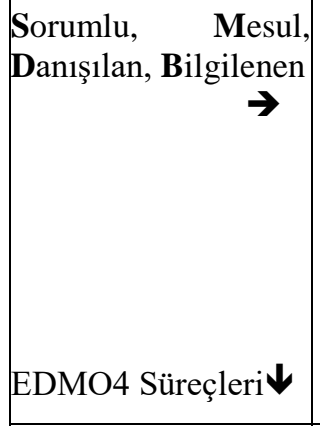 & $\frac{v}{\gamma}$ & $\underline{v}$ & $\mathscr{J}$ & 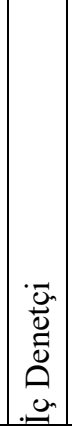 & 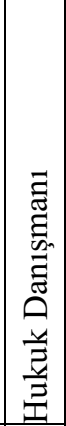 & 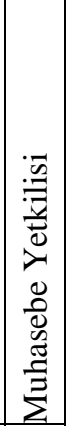 & 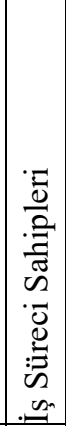 & 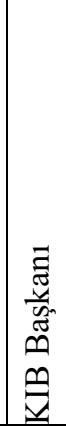 & 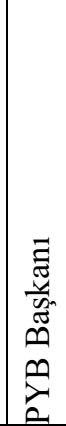 & 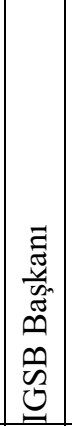 & 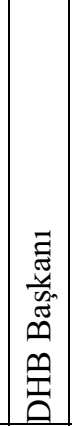 & 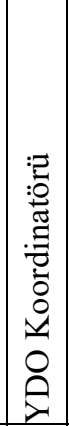 & 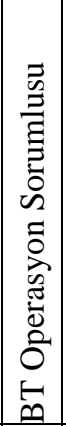 & 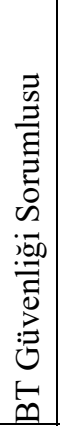 & 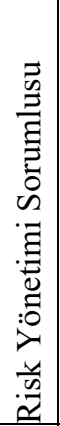 & 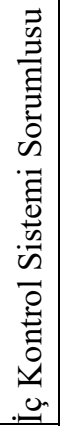 & 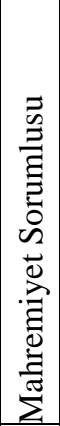 & 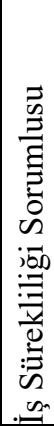 \\
\hline $\begin{array}{l}\text { Kaynak Yönetimini } \\
\text { Değerlendir }\end{array}$ & $\mathrm{M}$ & D & $S$ & D & $\mathrm{D}$ & B & B & $\mathrm{D}$ & D & D & D & D & $\mathrm{D}$ & $S$ & $S$ & $\mathrm{D}$ & D & $\mathrm{S}$ \\
\hline $\begin{array}{l}\text { Kaynak Yönetimini } \\
\text { Yönlendir }\end{array}$ & $\mathrm{M}$ & D & $S$ & $\mathrm{D}$ & $\mathrm{D}$ & & B & D & $\mathrm{D}$ & D & $\mathrm{D}$ & $\mathrm{D}$ & & & & & D & \\
\hline \begin{tabular}{|l}
$\begin{array}{l}\text { Kaynak } \\
\text { İzle }\end{array}$ \\
Iönetimini \\
\end{tabular} & & D & S & D & D & B & B & $S$ & D & $\mathrm{S}$ & $S$ & $D$ & & & $S$ & $S$ & D & $S$ \\
\hline
\end{tabular}

Kaynak: (ISACA, Enabling Processes, 2012: 43)' den uyarlanmıştır.

Yönetim kurulu (YK), kalkınma kurulu (KK), genel sekreter (GS), İç Denetçi, Hukuk Danışmanı Muhasebe Yetkilisi, İş Süreci Sahipleri, kurumsal iletişim (KIB) Başkanı, program yönetimi (PYB) Başkanı, iş geliştirme ve strateji belirleme (IGSB) Başkanı, destek hizmetleri (DHB) Başkanı, yatırım destek ofisi (YDO) Koordinatörü, BT Operasyon Sorumlusu, BT Güvenliği Sorumlusu, Risk Yönetimi Sorumlusu, İç Kontrol Sistemi Sorumlusu, Mahremiyet Sorumlusu ve İş Sürekliliği Sorumlusu olarak KA temel rolleri belirlenmiştir. Bu rollerin ne tür fonksiyonlarının olacağı ise her alt sürece göre ayrı ayrı belirlenmektedir. $\mathrm{Bu}$ roller personel imkanları ve iç ve dış paydaş ihtiyaçlarına göre farklı olarak da ifade edilebilir veya bazıları eklenerek çıkarılabilir. S, M, D ve B harfleriyle gösterilmiş olan sorumlu, mesul, danışılan ve bilgilenenlerin kimler oldukları da her KA dinamiklerine göre değişkenlik gösterebilir.

\section{a.Kaynak Yönetiminin Değerlendirilmesi (EDM04.01)}

Şimdiki ve gelecekteki kaynak ihtiyacı, kaynak oluşturma seçenekleri (kaynak temin stratejileri dahil) ve KA ihtiyaçlarını optimum şekilde karşılamak amacıyla tahsis ve yönetim prensiplerini sürekli olarak incelemek ve bu konuda karar almak gerekir. Sürecin girdisi olarak; Hedef yeterliliğinin sağlanmasındaki eksiklikler ve gerekli olan değişiklikler, beceri geliştirme planları ve tedarikçi değerlendirme 
kararlarının sonuçları dikkate alınırlarken, kaynak ve yetkinliklerin tahsisi için rehber prensipler, kalkınma ajansının mimarisi için rehber prensipler ve onaylanmış kaynak planı sürecin çıktısı olmalıdırlar.

Şekil 8: Kaynak Yönetimini Değerlendir (EDM04.01) Süreç Uygulama Modeli

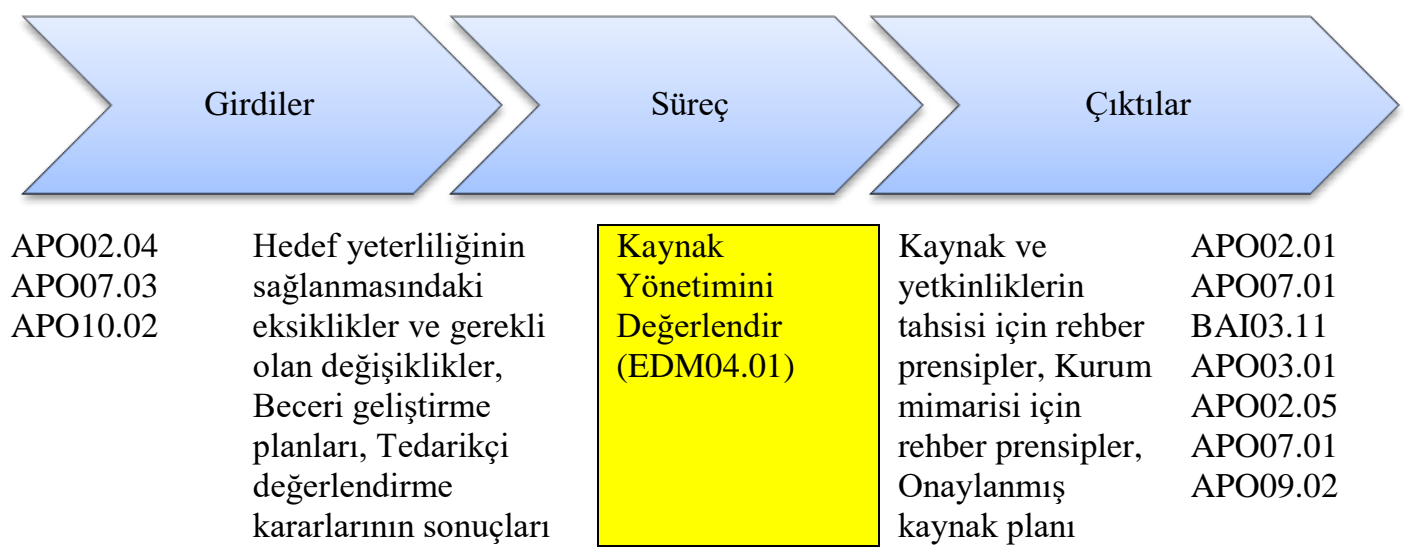

Kaynak: (ISACA, Enabling Processes, 2012: 44)' den esinlenerek araştırmacı tarafından hazırlanmıştır.

Kaynak yönetimini değerlendirme sürecindeki kriter faaliyetler aşağıdaki şekilde KA dinamikleri çerçevesinde uyarlanabilmektedir:

1. Şimdiki ve gelecekteki ihtiyaçları (kaynak temin seçenekleri dâhil) karşılamak için şimdiki ve gelecekteki strateji, BT kaynaklarının sağlanma seçenekleri ve gelişen yetkinlikleri incele ve bu konuda karar al.

Buna göre yapılacak başlıca alt düzey faaliyetler şunlardır:

- Kurumsal ihtiyaçların belirlenmesi

- Kurumsal ihtiyaçlar ile stratejilerin gerçekleştirilmesine olanak sağlayacak kadar kaynak olup olmadığının belirlenmesi

- BT alanındaki yenilikçi teknolojilere sarf edilecek kaynakların kurumsal stratejilere uyumlu olmasının sağlanması

- Kurumsal kaynakların kurumsal hedefler ve BT hedefleri doğrultusunda hizalanmasının sağlanması

2. BT'nin kalkınma ajansının ihtiyaçlarını, üzerinde anlaşılmış olan öncelikler ve bütçe kısitlamalarına uygun olan gerekli yetkinlik ve kapasiteyle karşılayabilmesi için, kaynak ve yetkinliklerin tahsisi ve yönetimini yönlendirmek amacıyla prensipleri tanimla.

Buna göre yapılacak başlıca alt düzey faaliyetler şunlardır:

- KA ihtiyaçları, öncelikleri ve finansal kısıtlarının belirlenmesi

-KA için gerekli yetkinlik ve kapasite düzeyinin belirlenmesi 
- YK tarafından kaynak kullanımında prensiplerin belirlenerek GS' ye kaynak kullanılmasinda yetkilerin devredilmesi

3. Değer oluşturulması ve riskin tahsis edilen kaynaklarla azaltılması amacıyla kaynak planı ve kalkınma ajansının mimari stratejilerini gözden geçir ve onayla.

Buna göre yapılacak başlıca alt düzey faaliyetler şunlardır:

- Kaynak planının ve bütçe planının oluşturulması

- Yerel yönetimlerden alınacak alacakların tahsilinin belirli bir program çerçevesinde yapılması ve bunların YK tarafindan onaylanması

- Kurumsal BT mimarisine ait stratejilerin gözden geçirilerek onaylanması

4. Kaynak yönetiminin, kalkınma ajansinın finansal ve insan kaynakları (HR) planlamasıyla hizalanmasına ilişkin gereksinimleri kavra.

Buna göre yapılacak başlıca alt düzey faaliyetler şunlardır:

- KA finansal ve HR planlamasının gözden geçirilmesi

- Kaynak ve planlama uyumunun gereksinimlerinin karşılaştırılması

- Gerekli kaynakların tahsis edilip edilmediğinin belirlenmesi

- Kaynak israfı ve gereksiz kaynak tahsis edilip edilmediğinin kontrol edilmesi

5. Kalkınma ajansının mimarisinin yönetim ve kontrolüne ilişkin prensipleri tanımla.

Buna göre yapılacak başlıca alt düzey faaliyetler şunlardır:

- BT kurumsal mimarisinin belirlenmesi

- Mimarinin yönetin standartlarının ve kontrol çerçevelerinin belirlenmesi

- Bunların KA ihtiyaçlarına göre belirli kurumsal prensipler haline getirilmesi

\section{a.Kaynak Yönetiminin Yönlendirilmesi (EDM04.02)}

BT kaynaklarının optimum kullanımını tam ekonomik yaşam döngüleri içinde gerçekleştirmek amacıyla kaynak yönetim prensiplerinin benimsendiğinden emin olmak gerekmektedir. Bu sürecin çıktıları olarak Kaynak oluşturma stratejilerinin bildirilmesi, kaynak yönetimine tahsis edilen sorumluluklar ve kaynakları koruma prensiplerinin meydana gelmesi gerekir.

Süreçteki kriter faaliyetler aşağıdaki şekilde KA dinamikleri çerçevesinde uyarlanabilmektedir:

1. Kaynak yönetim stratejileri, prensipleri ve üzerinde anlaşılmış olan kaynak planı ve KA mimari stratejilerinin benimsenmesini bildir ve sağla. 
Şekil 9: Kaynak Yönetiminin Yönlendirilmesi (EDM04.02) Süreç Uygulama Modeli

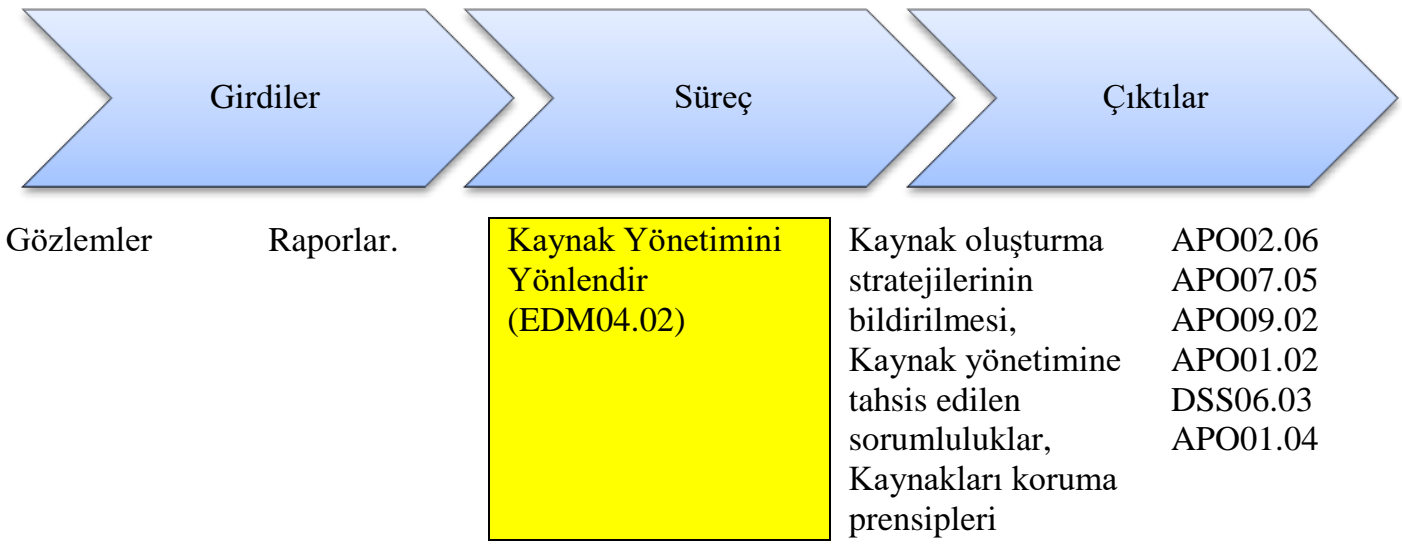

Kaynak: (ISACA, Enabling Processes, 2012: 44)' den esinlenerek araştırmacı tarafindan hazırlanmıştır.

Buna göre yapılacak başlıca alt düzey faaliyetler şunlardır:

- Kaynak yönetim stratejileri ve prensipleri ile planların benimsendiğini tespit et

- İlgili paydaşlara bildirilmesinin sağlanması

2. Kaynak yönetimini yürütmek amacıyla sorumlulukları tahsis et.

Buna göre yapılacak başlıca alt düzey faaliyetler şunlardır:

- Kaynak yönetimindeki aktörlerin belirlenmesi

- KB, YK ve KA içerisinde rollerin belirlenmesi

- Belirlenen roller için sorumlulukların tahsis edilmesi

3. Kaynak yönetimi için ana hedefler, kriterler ve ölçütleri tanımla.

Buna göre yapılacak başlıca alt düzey faaliyetler şunlardır:

- Kaynak yönetiminde ana hedeflerin belirlenmesi

- Hedeflere ulaşılıp ulaşılmadığını gösterecek ölçütlerin belirlenmesi

- Hedef ve ölçütlerin tanımlanması

4. Kaynakların korunmasıyla ilişkili prensipleri oluştur.

Buna göre yapılacak başlıca alt düzey faaliyetler şunlardır:

- Maddi kaynakların, beşeri sermayenin, bütçe olanaklarının, tahsil edilecek gelirlerin ve fikri hakların kimler tarafından ve nasıl korunacağının yönergelerde belirtilmesi

5. Kaynak yönetimini KA finansal ve HR planlamastyla hizala.

Buna göre yapılacak başlıca alt düzey faaliyetler şunlardır: 
- İnsan kaynakları yıllık planı ile ÇP karşılaştırmasının yapılması

- Faaliyet raporlarında KA kaynak yönetiminin finansal ve HR planlamasına dair değerlendirme yapılması

- İç de dış denetim raporlarında finansal ve HR yönetim ile ilgili risk analizlerinin yapılarak kontrol noktalarının test edilmesi

\section{b.Kaynak Yönetiminin İzlenmesi (EDM04.03)}

Kaynak yönetim süreçlerine ait ana hedefler ve ölçütlerin izlenmesi ve sapmalar veya problemlerin, iyileştirme amacıyla, nasıl tanımlanacağı, izleneceği ve raporlanacağını belirlemek gerekir. Kaynak ve yetkinliklerin tahsisi ve etkinliği konusunda geri bildirim ile kaynak yönetim sapmalarına yönelik iyileştirici eylemler bu sürecin çıktıları olmalıdırlar.

Şekil 10: Kaynak Yönetiminin İzlenmesi (EDM04.03) Süreç Uygulama Modeli

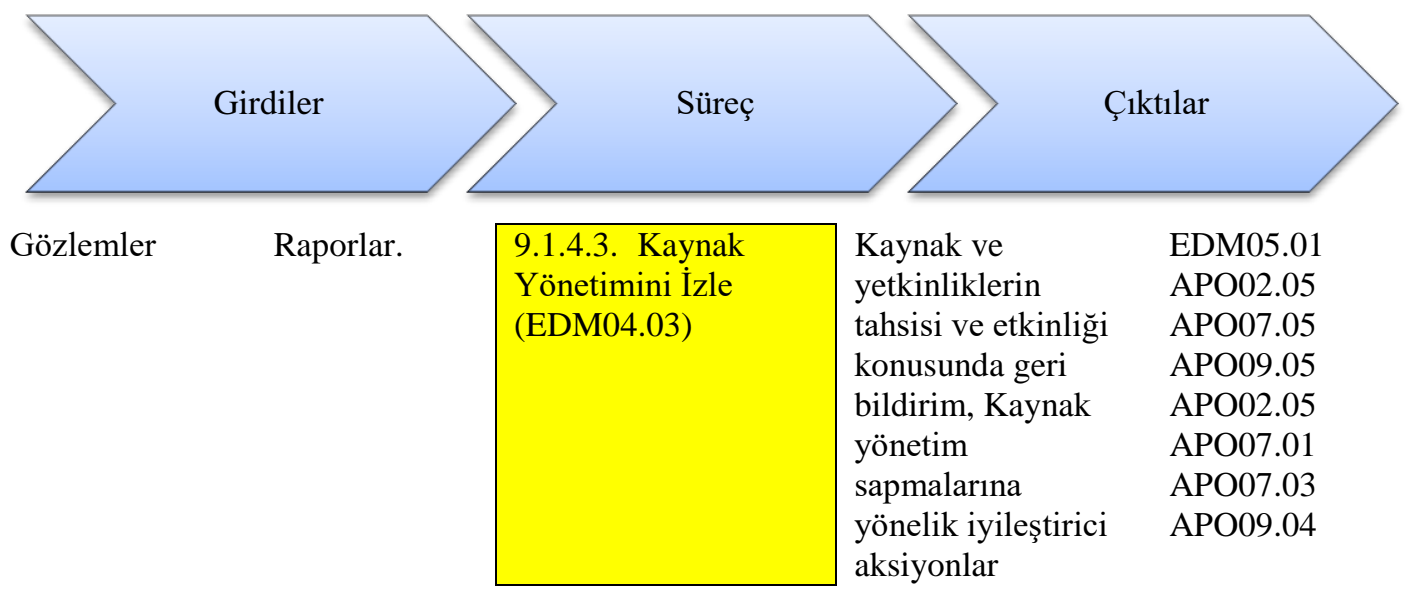

Kaynak: (ISACA, Enabling Processes, 2012: 44)' den esinlenerek araştırmacı tarafından hazırlanmıştır.

Süreçteki kriter faaliyetler aşağıdaki şekilde KA dinamikleri çerçevesinde uyarlanabilmektedir:

1. Kaynakların tahsisi ve optimizasyonunu, KA amaçları ve önceliklerine uyumlu olarak üzerinde anlaşılmış olan hedef ve ölçütler kullanarak izle.

Buna göre yapılacak başlıca alt düzey faaliyetler şunlardır:

•Önceden belirlenmiş ölçütlerin kullanılması

- KB ve YK tarafından KA kaynaklarının kurumsal hedeflere ve paydaş ihtiyaçlarına optimizasyonunun izlenmesi

- KK tarafindan kaynak optimizasyona dair değerlendirmeler yapılarak YK'na görüş verilmesi 
2. Şimdiki ve gelecekteki KA ihtiyaçlarının karşılanabilmesini sağlamak amacıyla, BT kaynak oluşturma stratejileri, KA mimari stratejileri, BT kaynaklar ve yetkinlikleri izle.

Buna göre yapılacak başlıca alt düzey faaliyetler şunlardır:

- KB tarafından BGUS çerçevesinde KA ihtiyaçlarına dair perspektif ve strateji analizi yapılarak KA kaynak ve yetkinliklerinin izlenmesi

- YK tarafından BKP ve ÇP uygulamasını etkileyecek kaynak oluşturma stratejilerinin izlenmesi

- GS tarafindan KA mimari stratejisi ile BT kaynak ve yetkinliklerinin izlenerek faaliyet raporlarına ve bir sonraki yıl ÇP hazırlıklarında dikkate alınması

3. Hedeflerle karşılaştırmalı olarak kaynak performansını izle, sapma nedenlerini analiz et ve altta yatan nedenlere yönelik iyileştirici aksiyonları başlat.

Buna göre yapılacak başlıca alt düzey faaliyetler şunlardır:

- BK tarafından KA kaynaklarının ÇP, bütçe programı ve faaliyet raporları sunumlarında performansın dikkate alınması

- KA performansının analiz edilerek ÇP ve BKP sapmalarının nedenlerinin incelenmesi

- Çekirdek nedenlerin tespit edilerek bunların YK ve GS ile paylaşılması

- YK ve GS tarafindan gerekli önlemlerin alınması

\section{Sonuç ve Değerlendirme}

Bir yönetişim hedefi ve süreci olarak kaynak optimizasyonu, KA açısından bölgesel ve kaynakların potansiyellere göre kullanılmasının sağlanarak yerel dinamiklerin harekete geçirilebilmesini sağlamak amacıyla yapılması gerekli olan bir uygulamadır. Özellikle kaynakların kıt olduğu ancak yerel paydaşlar ile bölgesel aktörlerin ihtiyaçlarının küresel rekabetçilik ortamında giderek artmasıyla fiziki, beșeri, maddi ve fikri kaynakların doğru bir şekilde tahsis edilerek istenilen sonuçların elde edilmesi bölgesel kalkınma için en hayati olan sorundur.

COBIT-5 kaynak optimizasyonu, bir yönetişim süreci olarak değerlendirilirken diğer süreçlerle olan etkileşim ve süreçlerle girdi-çıtı alışverişiyle birlikte dikkate alınarak modellenebilirliği gösterilmiştir. Bu amaçla da üç alt süreç olan kaynak yönetimini değerlendirmek, yönetmek ve izlemek gibi temel fonksiyonlarda gerekli olan kilit performans göstergeleri, kriter faaliyetler ile SMDB şeması oluşturulabilmiştir. Buna göre karar mekanizmalarıyla danışma ve denetim mekanizmaları da SMDB şemasında süreçte alacakları rollerine göre yerleştirilebilmiştir. 
- DDK tarafindan tespit edilen sorunlardan kaynak optimizasyonu ile ilişkili olan sorun var mıdır? Varsa hangileridir ve nasıl ilişkilendirilebilmektedir?

DDK tarafından tespit edilmiş olan sorunlardan ikisi olan "bölge kalınma planı (BKP) ve plancıların kalite sorunu" ve "verilen hibelerin kuruluş amaçları doğrultusunda kullanılamadiğı”, COSO ve COBIT-5 modelleri ile analiz edilebilmiştir. Buna göre, her iki sorunun da aslında kaynak yönetiminin doğru yapılamaması ve/veya sistemin yanlış kurgulanmış olmasıyla ilişkili olduğu tespit edilmiştir.

Kalkınma planlarının kaliteli olmaması yapılan projeksiyonların, hesaplamaların ve önceliklendirmelerin doğru olmayabileceği anlamına gelmektedir. Bu da kaynakların doğru tahsis edilmemesi ve bölgesel kalkınmayı ençoklayacak program ve projelerin desteklenmemesi demektir. Dolayısıyla kaynak optimizasyonunun yapılmamış olduğunun bir göstergesi olabilmektedir. Kaynak optimizasyonunu doğru bir şekilde yapabilmek de kalkınma planının gerekli nitelikleri haiz insan kaynağı tarafından hazırlanmasını gerektirir. Bu nedenle de insan kaynağının optimize edilmesiyle ilgili bir sorun olduğu söylenebilir. Bunun yanı sıra, hibelerin kuruluş amaçları çerçevesinde kullanılmaması bölgesel kalkınma için tahsis edilen kamu kaynaklarının israf edilmesi anlamına gelmektedir. $\mathrm{Bu}$ bağlamında bu sorunun da kaynak optimizasyonunun yapılmamasıyla ilişkilendirilebileceği ifade edilebilir.

- COBIT-5 kaynak optimizasyonu nedir ve KA dinamiklerinde nasil uygulanabilir?

COBIT-5 ile ortaya konulmuş olan kaynak optimizasyonu yaklaşımı bütüncül ve kapsamlıdır. Buna göre fiziki, beşeri, mali ve fikri tüm kaynakların paydaş ihtiyaçları doğrultusunda şekillendirilmiş olan kurumsal hedefleri en iyi düzeyde gerçekleştirecek şekilde tahsis edilebilmesi için öncelikle bu konudaki süreç yaklaşımının diğer süreçlerle entegre olarak uygulanabilmesi için modellenmesi ve uyarlanması gerekir. Kaynakların optimize edilmesi karar mekanizmasının etkin işletilebilmesiyle ilgili olmasından dolayı bir yönetişim süreci olarak ele alınmaktadır. Bu süreç de kaynakları değerlendirme, yönetme ve izleme diye üç alt süreçten oluşmaktadır. Bu süreçlerin uygulanabilirliği de gene süreçte sorumlu, mesul, danışılan ve bilgilendirilen (SMDB) rollerin belirlenerek rollerinin ve görev tanımlarının gerektirdiği şekilde dâhil edilmelerini gerektirir. Bu da sürecin işletilmesi esnasında gerekli olan kilit göstergeler ile kriter faaliyetlerin doğru belirlenerek uygulanmasıyla ilişkilidir.

KA dinamiklerinde bölgesel kaynakların optimize edilebilmesi bölgesel kalkınma açısından hayati öneme sahiptir. Çünkü özellikle merkezi plancılıkta ihtiyaçlar ve sorunlar merkezden doğru olarak tespit edilemediğinden dolayı mevcut beşeri ve mali sermaye ile maddi ve manevi olanaklar doğru bir şekilde tahsis edilmediğinden kaynakların yanlış kullanımı söz konusu olmasından dolayı yerel, bölgesel ve ulusal kaynaklar israf edilebilmekteydi. Bu nedenle yereldeki şartlara 
uygun bir şekilde gerekli planlamaların yapılarak paydaşlarla birlikte ortaya konulacak kaynakların bölgesel kalkınma amacı doğrultusunda seferber edilmesi amacıyla KA kuruluşları yapılmıştı. KA bütçeleri de sadece merkezi hükümet tahsisatı değil aynı zamanda yerel birlikler, kamu kurum ve kuruluşları ile belediyelerden de kaynak konulması prensip olarak Kanun tarafından gerekli kılınmıştı. Ancak zamanla tahsis edilen kaynakların doğru kullanılmadığı, yandaş kimselere proje adı altında haksız kazanç kapısı oldukları, uygulanan projelerin etkilerinin bölgesel kalkınma açısından olabildiğince önemsiz olduğu gibi değerlendirmeler yapılabilmesi bölgesel kalkınma için ayrılan kaynakların doğru kullanılmadığını ortaya koymaktadır. Dolayısıyla kaynakların optimize edilebilmesi aslında KA açısından varlık nedeninin yerine getirilip getirilmediği anlamında fikir verebilir. Uluslararası ölçekte genel kabul görmüş olan COBIT-5 yaklaşımıyla kaynak optimizasyonunun yapılabilirliğinin ortaya konulması KA açısından bazı kurumsal sorunları giderebileceği ve bölgesel gelişme hedeflerine ulaşmada yardımcı olabileceğinin ortaya konulabilmesi bu anlamda büyük öneme sahiptir.

Yapılan analiz ve modellemeler sonucunda KA özelinde bölgesel kalkınma dinamiklerinde bölgesel ve kurumsal kaynakların nasıl optimize edilebileceğine dair gerekli uygulama çerçevesi olarak bir süreç uygulama modeli kaynak yönetimini değerlendirme, yönlendirme ve izleme olarak alt süreçler üzerinden oluşturulabilmiştir. $\mathrm{Bu}$ süreçlerin işlerliğinin temin edilmesi için de SMDB şemaları, süreç hedefleri ve kriter faaliyetlerin tesis edilebilirliği ortaya konulabilmiştir.

\section{Kaynakça}

Bartens, Y., Haes, S. d., Lamoen, Y., Schulte, F., ve Voss, S. (2015). On the Way to a Minimum Baseline in IT Governance: Using Expert Views for Selective Implementation of COBIT 5. 48th International Conference on System Sciences. Hawaii.

Brown, W. C. ( 2014). The Failed Vasa: COBIT 5 and the Balanced Scorecard . COBIT Focus.

DDK, Aykın, H., ARSLANBAŞ, M., DERE, A., ÖZÇELİK, A., BOYALI, C., ÖZKILINÇ, M. A. (2014). Kalkınma Ajansları Inceleme ve Araştırma Raporu (Hizmete Özel). Ankara: Cumhurbaşkanlığı Devlet Denetleme Kurulu, http://www.tccb.gov.tr/faaliyetler/ddkraporlari/.

Efe, A. (2015). Türkiye'de Kalkınma Ajanslarl için Bir Yönetişim Modellemesi: COBIT-5. Ankara: TODAİE (Basılmamış Doktora Tezi).

Glenn Leary, K. M. (2007). Performance and Resource Optimization of NoC Router Architecture for Master and Slave IP Cores. Journal of IEEE, 155 - 160. 
Gunnar Lucko, A. (2011). Integrating Efficient Resource Optimization and Linear Schedule Analysis with Singularity Functions. Journal of Construction Engineering, 45-55.

Hwang, S. S. (2004). Trusted Grid Computing with Security Assurance and Resource Optimization. 17th International Conference on Parallel and Distributed Computing Systems (PDCS-2004), 15-17.

ISACA. (2012). COBIT 5: A Business Framework for the Governance and Management of Enterprise IT. Rolling Meadows, IL: ISACA.

ISACA. (2012). COBIT 5: A Business Framework for the Governance and Management of Enterprise IT. Rolling Meadows, IL: ISACA.

ISACA. (2012). Enabling Processes. USA: ISACA.

John Hof, B. K. (305-323). Chance Constraints and Chance Maximization with Random Yield Coefficients in Renewable Resource Optimization. Journal of Forest Science, 1992.

KB-BGYUGM. (2014). Devlet Denetleme Kurulu Kalkinma Ajanslari Araştirma ve Inceleme Raporu Kapsaminda Alinacak Tedbİler. Ankara: Kalkınma Bakanlığı (hizmete özel).

L. Egle, O. Z. (2004). The Austrian P budget as a basis for resource optimization. Resources, Conservation and Recycling, 152- 162.

Michael Stadler, P. P. (2005). Integral Resource Optimization Networks And Their Techno-Economic Constraints. International journal of distributed energy resources, 299-320.

Moses Charikar, J. (. (2000). Resource Optimization in QoS Multicast Routing of Real-Time Multimedia. journal of IEEE INFOCOM, 1518-1618.

Parvizi, R., Oghbaei, F., ve Khayami, S. R. (2013). Using COBIT and ITIL frameworks to establish the alignment of business and IT organizations as one of the critical success factors in ERP implementation. 5th Conference on Information and Knowledge Technology (IKT), (s. 978-1-4673-6490-4/13/\$31.00 IEEE).

Samiotakis, M. (2013). "Integrating ITIL and COBIT 5 to Optimize IT Process and Service Delivery. 6th itSMF South East Europe Conference. Athens.

Wilkin, C., Campbell, J., Moore, S., ve Grembergen, W. V. (2013). CoCreating Value from IT in a Contracted Public Sector Service Environment: Perspectives on COBIT and Val IT. Journal of Information Systems, 283-306.

Yong Jiang, J. D. (2006). Risk-Based Resource Optimization for Transmission System Maintenance. Journal Od IEEE Transactions on Power Systems, 11911201. 